\title{
Authentic Ecological Restoration
}

In July, I participated in a two-day meeting dubbed "Restoring or Renaturing? The Presence of the Past in Ecological Restoration: A Transatlantic Workshop." The meeting, which was held at the Zurich Botanical Garden in Switzerland, was hosted by environmental historian Marcus Hall and featured speakers from Europe, Canada, the United States, and Japan. The group included many environmental historians and a smaller contingent of ecological restorationists, paleoecologists, anthropologists, and environmental activists.

Marcus envisioned the gathering as a discussion that would lead to a better understanding and implementation of ecological restoration practice. He suggested that our interdisciplinary dialogue would focus on questions such as:

- Which conditions should be brought back, and do such conditions represent new natures or betters pasts?

- What historical assumptions do we hold when we set out to restore, and what are the political and social implications?

- What can the historical record tell us about the nature of degradation?

- Can rewilding be a legitimate goal in Europe, or is this a Holy Grail better pursued in the New World?

- How can restoration history improve our current efforts to restore?

Answers to, or at least discussions of, these and other questions, he reasoned, would help ecological restorationists on both sides of the Atlantic understand the commonalities and differences of their practices.

I guess we can all have great hopes for conferences, workshops, meetings, and the like. I know that both Marcus and I did for this one. In my estimation, however, a meaningful interdisciplinary discussion didn't occur at this meeting. We spent too much time simply trying to stay on schedule with our appointed presentations. That isn't to say that there weren't some excellent presentations - those by David Lowenthal, Daniel McCool, and Eric Higgs come quickly to mind.

Eric spoke after I did, and a comment he made during our subsequent panel discussion especially hit home with me. He said that he felt that too many ecological restorationists, including many of the current leading thinkers and opinion makers, had forgotten that a certain level of historical fidelity (a term Eric uses to mean "a loyalty to predisturbance conditions") is necessary in ecological restoration projects. Like Eric, I have seen ecological restoration move solely from a practice intended to care for the land and its other-than-human beings to a practice that involves a large element of social activism and human-centered concerns. I suggest you read Keith Bowers' SER International column in this issue to see my point. This shift, or additional emphasis on human-centered goals, is a significant one. It raises questions about the practice and activities we call ecological restoration.

Reflecting back on the Zurich workshop, I've come to realize that the "elephant in the room" was the lack of attention that we all paid to the idea of historical fidelity (what I will refer to here as authenticity or genuineness) and its relation to ecological restoration, renaturing, or whatever re- activity you want to name.

The dictionary definition of "authentic" indicates that the word describes some thing or some one "conforming to fact and therefore worthy of trust, reliance, or belief; having an undisputed origin, genuine; bona fide, unquestionable, veritable." In common vernacular, an authentic person or thing is "the real deal." The word "genuine" is similar and has even closer etymological roots to our subject. It comes from Latin word, "genuinus," which means "native, natural," which itself is from the word "gignere" or "beget" (which is also the root word for genus). In this same vein, the Latin word "genu," which means knee, recognizes the ancient custom of a father acknowledging paternity of a newborn by placing the child on his knee. So, take your pick-authentic or genuine-they both indicate a sense of known origin and, perhaps more importantly, a badge of legitimacy and credibility.

So, why did we avoid this discussion at the workshop? We had our opportunities-Nicki Whitehouse's excellent talk about the value of paleoecological studies of Irish peatlands and their value to biological and cultural conservation was one. Nothing. Daniel McCool's report on his work for a new book, The River Commons, gave us an opening when he emphatically stated, "eco-authenticity fails in the face of political will." No takers. Similarly, when activist Josh Donlan gave his pitch for rewilding North America with Pleistocene megafauna. Eileen Crist's presentation about the use of cloned extinct and/or endangered animals brought no response, either.

This lack of reaction leads me to believe that either we were all so happy to be in an air-conditioned auditorium and out of Zurich's heat wave that we weren't thinking or that creating or attempting to create an authentic or genuine ecosystem is no longer what people consider as ecological restoration. There were, in fact, many talks about ecological restoration solely or 
largely with a focus on human goals. Perhaps, the question at the end of Mark Bain's abstract about his work restoring the Hudson River Park after the 9/11 attack summed it up best: "What restoration strategy is appropriate for a humanized system?"

When I first began my studies in ecological restoration at the University of Wisconsin-Madison, we made a field trip to the UW Arboretum's Greene Prairie, which the botanist/mycologist Henry Greene had planted by himself over the course of about 15 years, beginning shortly after World War II. Upon its completion, Greene Prairie was a beautiful example of authentic ecological restoration-a project that was loyal to the ecology of the wetmesic prairie ecosystem that Greene made every effort to replicate and restore. Much of the magic of that restored prairie remains today, despite encroaching stands of invasive reed canarygrass, and, like an Alfonso Ponticelli cover of a classic Django Reinhart jazz guitar solo, it swings through the seasons with a powerful yet nuanced sense of beauty and faithfulness to itself and Greene's reference sites.

Now, it may be that Greene Prairie is an exception to the rule (although it is certainly not alone in terms of projects that have been wedded to an authentic baseline), and it's certainly true that Greene was meticulous in his work and generally unburdened by outside influences. Nevertheless, this type of approach serves as an ideal that every ecological restoration project should aspire to- a strong attention to detail, a use of existing sites and/or historical reference information to determine the predisturbance conditions, and a conviction that this approach will be the best way to restore ecosystems that are in danger of being lost or otherwise compromised. Yes, we can argue about whether the restoration of processes or structure or both are needed, but what we cannot fall prey to is the seemingly incessant need to put humans and human values first and foremost. As Dennis Martinez has pointed out, we must reestablish a kincentric relationship with the rest of Nature; we must become, as Aldo Leopold wrote, "citizens of the land community." Paying attention to the historical fidelity or genuineness of our projects can help greatly to move us in that direction by forcing us to look deeply into those beings and forces we seek to unleash so that they may pursue their way of life. Otherwise, we are likely to fall prey to the mass consumerism that surrounds us-creating gardens where we maintain beings as "things" strictly for our use and admiration.

I recognize that some will criticize me for being stuck in the past; that I am failing to see the potential of ecological restoration and the future. They may be right. However, I feel it is necessary for some people, like Eric and myself, to stand up and say that, in terms of ecological restoration, the past is important, that it does makes a difference, and that a study of past conditions serves as one of the most important foundations of an ecological restoration project. I certainly recognize that possibility is always more tantalizing than actuality or the past, and that we shouldn't feel that we are captives of our past. But rather than simply denying that the past matters, I strongly encourage practitioners to engage in a dialogue that includes both actuality and possibility, both past and future. By doing so, we will ourselves become more authentic and, likewise, produce more genuine restoration projects.

$$
* * *
$$

This editorial marks the end of my stay as a member of the staff of Restoration $\mathcal{E}$ Management Notes/Ecological Restoration. In general, the 20 plus years I was with the journal were an extremely positive and productive experience. I have many people to thank for making it so. The first, of course, is Bill Jordan, the journal's founder, editor, and guiding light for two decades. Bill played a huge role in my development as an editor, writer, and thinker about ecological restoration. The decade of the 1990s that we spent working together on this journal, I will always think of as our time and remember it well. Thanks, Bill. I also want to extend my warmest appreciation to Mary Ann Pels, who began working with Bill and me in the late 1990s, and began her time as the journal's associate editor during my stint as editor. Mary Ann and I formed a solid friendship that continues to this day. We encouraged and supported each other through some tough times and laughed through the good times. I still expect to see her when I open the door to my new office even though I know full well that she's 1,700 miles away. My many other colleagues at the Arboretum also deserve recognition for their support, and I wish them well as that institution finds a way to incorporate its glorious heritage with its future possibilities. I also have had a long and cheerful relationship with the folks at the University of Wisconsin Press Journals Division-Steve Miller, John Delaine, Susan Kau, Adrienne Omen, Ken Sullivan, Rita Emmert, and Judith Choles. Keep up the good work! I want to thank Kevin Ducey and Bridget Brown for their many hours of work on the Eco layout-solving all kinds of problems that I threw their way. A big thanks to Julie Hayward for her tireless efforts proofreading manuscripts and for providing me a country hideaway when needed. Thanks go out to many others, especially the various abstractors I've worked with, the members of the Editorial Advisory Board, and Joy and Paul Zedler for their continuing help with the journal. I also want to recognize efforts of the staff and board of the Society for Ecological Restoration International, with whom the journal has had a long and fruitful relationship. Thanks most of all to the readers of Restoration $\mathcal{E}$ Management Notes/Ecological Restoration. I trust that you'll continue to find the journal a leading source for information about the practice we all care so deeply about.

So, what am I doing? As of October 2, I took a position as editor/writer with the Ecological Restoration Institute at Northern Arizona University. I am working with Wally Covington, Diane Vosick, and the rest of the ERI staff to help forge a new paradigm of restorative land care for the frequent-fire forested landscapes of the southwestern United States. It's definitely an out-of-bioregion move for me, but I'm looking forward to learning the ropes here and enjoying the climb.

The past endures. The present is. The future beckons.

Dave Egan

Dave.Egan@nau.edu

928/523-5697 